УДК 378.018.8:001.814]:005.336.2(045)

https://doi.org/10.33296/2707-0255-11(21)-09

KHARKIVSKA ALLA

Doctor of Pedagogy,

Vice-Rector of Research and Educational

Work,

Municipal Establishment 'Kharkiv

Humanitarian-Pedagogical Academy'

of the Kharkiv Regional Council,

Kharkiv, Ukrain

https://orcid.org/0000-0003-4782-1079

MALYKHINA VALENTINA

Candidate of Pedagogical Sciences,

Professor of the Department of Pedagogy,

Psychology,

Primary Education and Educational

Management, Municipal Establishment

Kharkiv Humanitarian- Pedagogical

Academy'of the Kharkiv Regional

Council,

Kharkiv, Ukraine

https://orcid.org/0000-0003-3335-9119

\title{
INSTRUMENTAL COMPETENCIES OF HIGHER EDUCATION SEEKERS AS A FACTOR OF PROFESSIONAL TRAINING
}

\footnotetext{
Abstract. The article is carried out an analysis of the competence-based approach, which is characterized by the broader boundaries of research and development, because it reflects best practices, takes into account the future requirements of the labor markets. Ways of targeting the learning process on the development of student's personality, the formation of its instrumental competencies are examined in the article. For example, the study of "General course of Physics" attempts to explain the formation of competencies of future teachers. At the present stage the national education system is one of the priorities of our country development strategy The democratic basis of the reforms has identified the degree of higher education development, which enables to detect the degree of the autonomy of the higher educational institutions, educational and personnel policy, implement the system of education in new stages of national education development that has the aim to train new formation specialists who know how to apply the knowledge and technologies in different spheres of activity motivated by the constant self-education. Competence approach requires the

(c) Українська інженерно-педагогічна академія

(c) ГО «Школа адаптивного управління соціально-педагогічними системами»

(C) Харківська А., Малихіна В
} 
inculcating and developing in students a set of core competencies that define its successful adaptation in society. In addition competencies include the purely professional knowledge and skills that characterize the qualification of such qualities as initiative, cooperation, the ability to work in a group, communication skills, ability to learn, evaluate, think logically, and use the information. Competence is manifested in student-oriented activities. So the manifestation of competence is assessed on the basis of the total graduate`s skills formedness (that integratively reflects this competence) and its behavioral (psychological) reactions that are manifested in a variety of situations. Availability of the prevailing instrumental competencies of future teachers is a major factor in their professional training.

Keywords: competence approach, competency, competence, instrumental competencies.

Target setting. In modern conditions of innovative development of our State the fundamental change of educational paradigm exists. An educational establishment must not only give professional knowledge, but also form the variety of professionally relevant and socially important personal qualities (competencies) that describe the social portrait of the future specialist, contribute toward successful employment and further professional and personal growth of graduates.

The main task of higher educational establishments is to improve the quality of education according to modern and prospective implementation of competence approach. This task is associated with overcoming several problems that exist in the educational process. The main problems of designing and implementing educational programs are the following: preserving orientation informationknowledge model of higher professional education; weakened block of activitycompetence learning outcomes (in particular, little attention is paid to the formation of the instrumental competencies of future professionals); declaratory nature of the texts; understated assessment-diagnostic potential; lack of adaptability to the requirements of the modern school, that demand much of the graduates-future teachers; overload of higher educational content while maintaining the priority of academically oriented programs (over the 
professionally oriented); lack of personal focus of the educational process; "exclusion" from the technological and poor representation of basic skills (qualifications, competencies) that are of highly professional nature; a partial list of world tendencies in the development of higher education; prevalence of differentiated scientific view of the world, imbalanced with the processes of integration and strengthening the interdisciplinary studies [2]

Analysis of recent research and publications. As it is pointed out by S. Adam, A. Boreichuk, S. Bergan, D. Mink, S. Lisova, Georges T. Roos standard may not be enforced in the deployment of complex processes of diversification of higher education and what is more serve as the official reproduction norm of uniform amount of professionals.

The founder of the Swiss Research Institute, famous in Europe, an expert in the field of Labour Sociology Georges t. Roos says: ... It is necessary to have the competences. For someone who is looking for work, this means that it must be a universal worker (employee, who has 'a portfolio of competences' - PortfolioWorker): he should have a variety of skills, based on his own talents and recognized by the original combination of practical experience. Instead of performing the task the ability to solve problems is required. Workers are becoming increasingly independent with significant market responsibility [8].

Statement of the main material. Considerable attention of experts today is paid to the competence approach, that it is common to have more broad boundaries of research and development, it covers more than particular work requires; reflects best practices; takes into account the future requirements of the labor markets.

At the present stage the national education system is one of the priorities of our country development strategy. The democratic basis of the reforms has identified the degree of higher education development, which enables to detect the degree of the autonomy of the higher educational institutions, educational and personnel policy, implement the system of education in new stages of national 
education development that has the aim to train new formation specialists who know how to apply the knowledge and technologies in different spheres of activity motivated by the constant self-education.

Guideline preparation of competitive specialists, namely the future teacher, became correspondence technology training in high school to the principles of the Bologna process. In this regard, competence approach is based on the Ukrainian strategy of higher education modernization in the conditions of credit technology of training.

The competence approach refers to a method of education results modeling as norms of the quality standards of higher education [2]. We presume that, in the framework of the competence approach all educational standards are covered: such as minimum content, requirements for graduates and maximum workload.

Competence approach combines the meaning of both terms 'competency' and 'competence'.

Competence approach assumes that: 1) standards of higher vocational education act primarily as a result of the educational standards of education; 2) competence approach itself is a method of modeling and designing educational results and their reflections in the standard [4].

Competence approach requires the inculcating and developing in students a set of core competencies that define its successful adaptation in society. In addition competencies include the purely professional knowledge and skills that characterize the qualification of such qualities as initiative, cooperation, the ability to work in a group, communication skills, ability to learn, evaluate, think logically, and use the information.

According to the Bologna requirements of competency-based approach is implemented in the Dublin descriptors that are based on the five main learning outcomes: knowledge and understanding, practical use of knowledge and skills, the ability of making judgments, evaluating ideas and formulation of conclusions, 
skills in the area of communication and training.

In the framework of the proposed use (in the standards of new generation) of competence approach along with a category of "competency" you need to specify also the notion of "competence". The competence is understood to mean the integrated characteristic qualities of the personality, the training of the graduate for the performance of activities in certain areas (of competences). Competency, as well as competence, includes cognitive (educational), motivational and emotionalvolitional components. Competence is a situational category, expressed in readiness to act in any specific professional (distressed) situations.

Purpose of the article is to show how the formation of competencies in future teachers of municipal establishment 'Kharkiv humanitarian pedagogical Academy' of Kharkiv regional Council while performing tasks at practical, lecture classes and club activity.

Competence is manifested in student-oriented activities. So the manifestation of competence is assessed on the basis of the total graduate`s skills formedness (that integratively reflects this competence) and its behavioral (psychological) reactions that are manifested in a variety of situations.

S. Bergan highlights: 'General competences are considered as the ability, based on knowledge, experience, values, aptitude, which is formed in all three types of educational practice: formal, informal. General competence is sometimes called instrumental, impersonal and systematic' [3].

According to this in higher education within the Bologna process competencies differ in subject (related to the subject area) and general (for all courses, modules of the educational process). General competencies include instrumental competence, which includes: cognitive abilities (ability to understand and use knowledge and ideas); methodological capacity (the ability to organize and efficiently manage environmental factors (arrange time to build learning strategies), the ability to make decisions and solve problems); technological skills 
(skills related to the use of the equipment; computer skills and knowledge of information management); language skills (verbal or written communication or knowledge of a second language; interpersonal and system expertise.

Particularly instrumental competence consists of the following competencies: ability to analysis and synthesis; capacity for organization and planning; the availability of basic general knowledge; Basic knowledge for the profession; communication skills in your native language; communication skills in a foreign language; elementary computer skills; skills in information management; the ability to receive and analyze information from various sources; ability to solve problems [10].

Instrumental competence: is a set of competencies such as (the capacity for analysis and synthesis; the capacity for organization and planning; basic knowledge in different areas; thorough training on the basics of professional knowledge; written and verbal communication in their native language; knowledge of the second language; Basic computer skills; information management skills (the ability to find and analyze information from different sources); solve problems; decision making) that perform the instrumental function.

Instrumental competence, namely, the competence of which they are composed, are well clarified and match for many approaches; for example, the technological competence (which is understood as the use of a personal computer) or linguistic competence (verbal and written communication).

For example, on the second and third years, students of Kharkiv humanitarian pedagogical academy (according to the curriculum) study the discipline 'General course of Physics': attending lectures, practical classes, physics and mathematics club, etc. During training students will learn about the physical phenomena and the laws of physics, their applicability, the application of the laws in the most important practical applications; get acquainted with the main physical values, exploring their definition, content, methods and measurement of their 
units; conduct fundamental physical experiments, make the conclusion about their role in the development of science; aware of the purpose and principles of action of the major physical equipment.

In addition, such skills as working with instruments and equipment of modern physical laboratory; using various methods of physical measurements and processing of experimental data; conducting adequate physical and mathematical modeling, and application of the methods of physical-and-mathematical analysis to solve specific science and technical problems are formed in students. The students know the basic laws of physics; can apply for solving the problems arising in their.

This indicates that, while studying 'General course of Physics', the following instrumental competences are formed.

- ability to apply knowledge about physical objects and phenomena in practice, including nominate hypothesis, formulate the theoretical physical models, conduct analysis of the limits of their use;

- ability to plan and conduct physical experiments adequate experimental methods, to assess the precision and accuracy of measurements, analyze the physical meaning of the obtained results;

- ability to use knowledge of the basic physical theories to solve their fundamental and practical tasks, independent acquisition of knowledge in physics, forthe understanding of the principles of appliances operation and devices, including going beyond the competence of particular direction;

- willingness to apply analytical and numerical methods of physical tasks solution of using languages and systems of programming toolkits for computer modeling;

- ability to use knowledge about the structure of matter, physical processes in substance, different classes in natural substances to understand the properties of materials and mechanisms of physical processes occurring in nature;

- possess the mathematical and natural - scientific culture, including in the 
field of physics, as a part of a professional and universal culture;

- ability to carry proof of assertions as a part of cognitive and communicative functions.

As you can see formed instrumental competencies of future teachers will need to be formed not only while studying at the University, but also during professional activities - working in educational establishments: schools, vocational schools, colleges etc.

Georges T. Roos believes that... in the future work will not only mean completing a task, but 'problem solving' and 'project management'. A new form of labor requires the ability to think in categories of process (prozesshuft) and be able to determine the purpose of the course of the case. The ability to think of different scenarios and act with consideration of several alternatives is needed. Creative teaching is the central task of the future. It should give the opportunity to the person of the future to take new decisions, to find new ways and generate new ideas [8].

'...professionalism ... is still a significant indicator of identity in our society' $[7,9]$.

Competence describes the ability of a person (specialist) to realize his human potential for professional activity.

Instrumental competencies of future teacher is the desire and ability (willingness) to realize his full potential (knowledge, skill, experience, personal qualities etc.) for successful creative (productive) activity in a professional and the social sphere shown by him in practice, fully consciousness of its social importance and personal responsibility for the results of his activity, the need for its constant improvement. In the manual Prime (Research and Development) the concept of "competent, competency, competence are distinguished. Competency (adjective) in the sense of high activity ('competent person';).

Competency (noun): to be competent ('competence of Pedagogy', 'teacher competence'). 
Competence (noun) has a double meaning: tasks performed by some entity (for example: 'implementation of laboratory work') and the personal quality of some entity ('leadership';'discernment'). Both last meanings appeared in the United States. In addition, highlighting the wide and narrow views on competence, the narrow view means adherence to rules and procedures, the use of technical/professional skills for performing common tasks; wide view provides the requirements that are greater than are needed for a particular job, corresponding to the best existing practice and future labor-markets.

It is about two approaches to competences: reflective (reflection of current practices and what people can do in the present) and strategic (competence determined by the prediction of future needs. and there are stimulating, aimed not only at what is happening 'here and now') [5].

Expert on the Bologna process of the European Council Stephen Adam (University of Westminster), a well-known researcher of educational outcomes and competencies, believes that 'competencies and competences to a certain degree are used in conjunction with learning outcomes. Competence may broadly refer to the abilities, skills, capabilities, understanding etc. Competent person is someone with sufficient skills, knowledge and abilities. Some scientists take narrower point of view and equate competence only to the skills acquired in the process of preparing' [4].

Steven Adam states that this term has no single understanding, TUNING project stipulates that competence and skills include knowledge and understanding '(theoretical knowledge in the academic area, the ability to know and understand),' the knowledge of how to act '(practical and operational application of knowledge in specific situations) and the knowledge of how to be (values that are an integral part of perception and living with others in a social context).

'Competence,' as Stephen Adam thinks, represent a combination of characteristics (for knowledge and its application, skills, responsibilities and 
positions and are used for the description of the level or degree to which a person can demonstrate them). In this context, the competence or the set of competencies means that person can demonstrate certain abilities or skills and perform a task so that it will assess the level of achievement. Competence can be demonstrated and, consequently, be assessed [4].

\section{So, note the following:}

1. You can explore that most of the definitions are based on the fact that: instrumental competence of future teacher - is a unity of theoretical knowledge and practical activity.

2. Instrumental competence can be regarded as the most common to describe the results of education. In this sense, they:

- exclude interference in the educational process, methods and technologies;

- contribute to the comparison and the confirmation of degrees while respecting the autonomy of the institution, its capacity for innovation and experimentation (establish general performance level);

- contribute to the development of training programs (the process of their

- design begins with the identification of learning outcomes);

- used for internal and external quality assessment of higher education using the identifier of the key competencies, namely: the capacity for analysis and synthesis; the capacity for organization and planning; Basic knowledge in various areas; thorough training on the basics of professional knowledge; written and verbal communication in their native language; knowledge of the second language; basic computer skills; information management skills (the ability to find and analyze information from different sources); solving problems; decision making.

3. Availability of the prevailing instrumental competencies of future teachers is a major factor in their professional training.

The prospective directions of professional training of instrumental competencies of higher education seekers in Ukraine are: development an ability

\footnotetext{
(C) Українська інженерно-педагогічна академія

(C) ГО «Школа адаптивного управління соціально-педагогічними системами»

(C) Харківська А., Малихіна В
} 
(willingness) to realize their full potential (knowledge, skill, experience, personal qualities etc.) for successful creative (productive) activity; consciousness of social importance and personal responsibility for the results of their activity; the need for constant improvement themselves.

\section{REFERENCES}

1. Boreichuk A. Zmistovo-strukturni osoblyvosti instrumentalnykh kompetentnostei maibutnikh yurystiv / A. V. Boreichuk // Psykholoho-pedahohichni osnovy humanizatsii navchalno-vykhovnoho protsesu v shkoli ta VNZ. - 2016. - Vyp. 1.- S. $19-25$.

2. O. Borodiyenko, Ya. Malykhina, A. Kalenskyi, T. Ishchenko Economic, psychological and pedagogical preconditions of implementation of result-based management Kharkiv Educational and Scientific Institute of the State Higher Educational Institution "University of Banking". Collection "Financial and credit activities: problems of theory and practice"- Vol 2, №33 (2020) S.535-546. Professional edition Included in the scientometric databaseWoSISSN:2306-4994; eISSN:2310-8770 Access mode:http://fkd.org.ua/article/view/161941 DOI: https://doi.org/10.18371/fcaptp.v2i33.207237

3. Koler YU. Obespechenie kachestva, akkreditacyi i priznanie kvalifikacij kak kontrol'nye mekhanizmy Evropejskogo prostranstva vysshego obrazovaniya / YU. Koler // Vysshee obrazovanie v Evrope. - № 3. - 2003.Lisova S.V. Profesiina pedahohichna osvita: kompetentnisnyi pidkhid: mono- hrafiia / za red. O. A. Dubaseniuk. - Zhytomyr: Vyd-vo ZhDU im. I. Franka, 2011.

- S. 34-5.

4. Stiven Adam «Peredovyi dosvid YeS v haluzi rozrobky ta vykorystannia standartiv vyshchoi osvity» / Adam Stiven // Mizhnar. konf.: «Uzghodzhennia osvitnikh standartiv ta prohram Ukrainy z NRK» 2 liutoho 2017 roku. - K.: Kyivskyi nats. un-t im. T.H. Shevchenka, 2017.

5. Model of Competence. Which reflects the needs of employment. Prime. Research and Development. 1999.

6. Münk Dieter. Beruf und Kompetenz // Kompetenzentwick-lung in der beruflichen Bildung. Leske + Budrich, Opladen 2002.

7. Roos T.G. Die Arbeitswelt im Jahre 2020: Was bedeutet sie für die Bildung (Leicht geändert für Thurgauer Zeitung, 18 Juni 2002).

8. Kharkivska, A. Teoretychni ta metodychni zasady upravlinnia innovatsiinym rozvytkom pedahohichnoho VNZ: monohrafiia / A. A. Kharkivska. Kh.: KhHPA, 2011. -364 s.

9. Kharkivska A. Motyvatsiia maibutnikh uchyteliv fizychnoho vykhovannia do profesiinoi diialnosti ta samorozvytku osvity / A. A. Kharkivska // Visnyk LNU imeni Tarasa Shevchenka. Seriia: Pedahohichni nauky": zb. nauk. pr. / LNU im. T. 
Shevchenka, 2017. - № 153. - S. 150-155.

10. U.Fedorova, K.Babenko, Ya.Malikhina,. O.Yarmosh, V.Malykhina Problems of training managers in the field of public administration and administration in the digital economy - Ukraine, Kharkiv Educational and Research Institute of the State Higher Educational Institution "University of Banking". Collection "Financial and credit activities: problems of theory and practice" - Volume 3, №30 (2019) P.501-509. Professional edition Included in the scientometric database WoSISSN: $2306-4994 ; \quad$ e-ISSN: 2310-8770 Access mode:http://fkd.org.ua/article/view/161941DOI:https://doi.org/10.18371/fcaptp.v3i30 .179926

ХАРЬКОВСКАЯ АЛЛА

доктор педагогических наук, проректор по научно-воспитательной работе, Коммунальное учреждение «Харьковская гуманитарнопедагогическая академия» Харьковского областного совета, г. Харьков, Украина

\title{
МАЛЫХИНА ВАЛЕНТИНА
}

кандидат педагогических наук, профессор кафедры педагогики, психологии, начального образования и управления образованием, Коммунальное учреждение Харьковская гуманитарнопедагогическая академия Харьковского областного совета, г. Харьков, Украина

\section{ИНСТРУМЕНТАЛЬНАЯ КОМПЕТЕНЦИЯ СОИСКАТЕЛЕЙ ВЫСШЕГО ОБРАЗОВАНИЯ КАК ФАКТОР ПРОФЕССИОНАЛЬНОЙ ПОДГОТОВКИ}

\begin{abstract}
Аннотация. В статье проводится анализ компетентностного подхода, который характеризуется более широкими границами исследований и разработок, поскольку отражает передовой опыт, учитывает будущие требования рынка труда. В статье рассматриваются пути ориентации учебного процесса на развитие личности студента, формирование его инструментальной
\end{abstract}

\footnotetext{
(C) Українська інженерно-педагогічна академія

(C) ГО «Школа адаптивного управління соціально-педагогічними системами»

(C) Харківська А., Малихіна В
} 
компетенции. Например, изучение «Общего курса физики» пытается объяснить формирование компетенций будущих учителей. На современном этапе национальная система образования является одним из приоритетов стратегии развития нашей страны. Демократическая основа реформ определила степень развития высшего образования, что позволило выявить степень автономии высших учебных заведений, внедрение системы образования на новых этапах развития отечественного образования с целью подготовки специалистов нового уровня, умеющих применять знания и технологии в различных сферах деятельности, мотивированных постоянным самообразованием.

Компетентностный подход требует развития у студентов набора основных компетенций, которые определяют его успешную адаптацию в обществе. Кроме того, компетенции включают чисто профессиональные знания и навыки, характеризующие формирование таких качеств, как инициативность, сотрудничество, способность работать в группе, коммуникативные навыки, способность учиться, оценивать, логически мыслить и использовать информацию. Компетентность проявляется в студенческой деятельности. Таким образом, проявление компетенции оценивается на основе общей сформированности навыков выпускника (интегративно отражающих эту компетенцию) и его поведенческих (психологических) реакций, которые проявляются в самых разных ситуациях. Наличие у будущих учителей превалирующих инструментальных компетенций является важным фактором их профессиональной подготовки.

Ключевые слова: компетентностный подход, компетентность, компетенция, инструментальная компетенция.

ХАРКІВСЬКА АЛЛА

доктор педагогічних наук, проректор з науково-виховної роботи, Комунальний заклад «Харківська гуманітарно-педагогічна академія» Харківської обласної ради, Харків, Україна

\section{МАЛИХІНА ВАЛЕНТИНА} кандидат педагогічних наук, професор кафедри педагогіки, психології, початкової освіти та управління освітою, Комунальний заклад «Харківська гуманітарно-педагогічна академія» Харківської обласної ради, Харків, Україна 


\section{ІНСТРУМЕНТАЛЬНА КОМПЕТЕНЦІЯ ЗДОБУВАЧІВ ВИЩОЇ ОСВІТИ ЯК ФАКТОР ПРОФЕСІЙНӦ̈ ПІДГОТОВКИ}

Анотація. У статті проводиться аналіз компетентнісного підходу, який характеризується більш широкими межами досліджень і розробок, оскільки відображає передовий досвід, враховує майбутні вимоги ринку праці. У статті розглядаються шляхи орієнтації освітнього процесу на розвиток особистості студента, формування його інструментальної компетенції. Наприклад, вивчення «Загального курсу фізики» намагається пояснити формування компетенцій майбутніх вчителів. На сучасному етапі національна система освіти $\epsilon$ одним із пріоритетів стратегії розвитку нашої країни. Демократична основа реформ визначила ступінь розвитку вищої освіти, що дозволило виявити ступінь автономії закладів вищої освіти, впровадження системи освіти на нових етапах розвитку вітчизняної освіти з метою підготовки фахівців нового рівня, які вміють застосовувати знання i технології в різних сферах діяльності, мотивованих постійною самоосвітою.

Компетентнісний підхід вимагає формування у студентів основних компетенцій, які визначають його успішну адаптацію в суспільстві. Крім того, компетенції включають чисто професійні знання і навички, що характеризують формування таких якостей, як ініціативність, співпраця, здатність працювати в групі, комунікативні навички, здатність вчитися, оцінювати, логічно мислити i використовувати інформацію. Компетентність проявляється в студентській діяльності. Таким чином, прояв компетенції оцінюється на основі загальної сформованості навичок випускника (інтегративно відображають цю компетенцію) і його поведінкових (психологічних) реакцій, які проявляються в самих різних ситуаціях. Наявність у майбутніх вчителів превалюючих інструментальних компетенцій $€$ важливим фактором їхньої професійної підготовки.

Ключові слова: компетентнісний підхід, компетентність, компетенція, інструментальна компетенція. 